\author{
Military Technical College \\ Kobry El-Kobbah, \\ Cairo, Egypt.
}

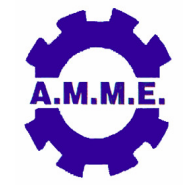

\title{
ENHANCING PROPERTIES OF CAST AL ALLOYS BY RHEO- CASTING AND NANO-DISPERSIONS
}

\author{
I. El Mahallawi ${ }^{1}$, Y. Shash ${ }^{1}$, R. Rashad ${ }^{1}$, H. Abdelkader ${ }^{2}$, L. Shehata ${ }^{3}$, \\ M. H. Abdelaziz ${ }^{4}$, A. Amer ${ }^{5}$, J. Mayer ${ }^{5}$ and A. Schwedt ${ }^{6}$
}

\begin{abstract}
In this work a number of cast samples of A356 and A390 were prepared by rheocasting in a specially designed and built furnace unit allowing for the addition of the nano-particles into the molten Al-Si alloy with mechanical stirring. The microstructure features and the mechanical properties of the cast samples were investigated, as well as resistance to wear and corrosion in laboratory tests.

The results obtained in this work showed improved wear and corrosion resistance of the nano-dispersed hypereutectic A390 alloys, as well as enhancement in the mechanical strength of the nano-dispersed hypoeutectic A356 alloys, accompanied by significant increase in the elongation percentage, supported by evidence of refined dendrite arms length, and inter-lamellar spacing. The work also shows significant enhancement in the wear and corrosion performance of the nanodispersed alloys.
\end{abstract}

\section{KEY WORDS}

Cast AISi alloys; rheo-casting; nano-dispersions.

\footnotetext{
${ }^{1}$ Prof., Faculty of Engineering, Cairo University.

${ }^{3}$ Lecturer, Ministry of Military Production.

${ }^{2}$ Faculty of Engineering, Helwan University.

${ }^{5}$ Graduate student, Ministry of Military Production.

${ }^{4}$ Graduate student, British University in Egypt.

${ }^{6}$ Prof., Aachen University, Germany.
} 


\section{INTRODUCTION}

Cast light metal alloys have retained their importance and unique characteristics as first candidates when cost-function relationship is considered. Hypoeutectic and hypereutectic aluminum silicon alloys as (A356, and A390) exhibit several specific and interesting properties that qualify them to be used in many automotive and aeronautical applications. Evidence of significant enhancement in strength and the properties of Al-Si cast alloys by incorporating nano-particles have been recently presented. Preliminary investigations [1-4] show that introducing nano-ceramic particles to (A356) has a beneficial effect on optimizing strength -ductility relationship in these alloys. Recent studies [5-7] also shows enhancements in strength, hardness, and tribological properties of hypereutectic Al-Si alloy (A390) by introducing reinforcement ceramic particles and it was concluded that as the reinforcement particles size goes smaller their effect is much more beneficial.

\section{EXPERIMENTAL WORK}

\section{Materials}

The base metal for the produced material was basically two types of cast Al-Si alloys: namely; hypoeutectic alloy A356 and hypereutectic alloy A390 the analysis of which is given in Table (1). The two alloys were chosen for their wide use in automotive and aeronautical applications.

Table (1): Chemical Composition (in wt. \%) of the base alloys.

\begin{tabular}{|c|c|c|c|c|c|c|c|c|}
\hline \multirow{2}{*}{ Alloy } & \multicolumn{7}{|c|}{ Chemical Composition (wt.\%) } \\
\cline { 2 - 9 } & Si & Mg & Fe & Cu & Ti & Zn & Mn & Al \\
\hline A356 & 6.60 & 0.30 & 0.14 & 0.09 & 0.075 & 0.006 & 0.005 & Bal. \\
\hline A390 & 17 & 0.45 & 0.5 & 4.5 & 0.2 & 0.1 & 0.1 & Bal. \\
\hline
\end{tabular}

The material used for reinforcement was $\mathrm{Al} 2 \mathrm{O} 3$ and $\mathrm{TiO} 2$ ceramic nano-particles with constant particle size of $50 \mathrm{~nm}$, the description of which is given in Table (2).

\section{Equipment}

\section{Furnace description}

An electrical furnace was designed and constructed for this research work for preparing the nano-dispersed alloys. It consists of a lift out graphite crucible of max. $8 \mathrm{~kg}$, heating system, and is connected to a stirring mechanism of max motor 3000 $\mathrm{rpm}$ with variable height and a control unit up to $1200{ }^{\circ} \mathrm{C}$ with a thermocouple for controlling the temperature stirrer (Fig.1). 
Table( 2): Properties of typical discontinuous $\mathrm{Al} 2 \mathrm{O} 3$ and $\mathrm{TiO} 2$ reinforcement.

\begin{tabular}{|l|c|c|}
\hline \multicolumn{1}{|c|}{ Reinforcement } & X-Al2O3 & TiO2 \\
\hline Density (Solid) (g/cm3) & 3.60 & 4.23 \\
\hline Crystal Structure & FCC & Tetragonal \\
\hline Appearance & White Solid & White solid \\
\hline Young ,s Modulus (GPa) & 380 & 244 \\
\hline Average Size (nm) & 50 & $40-50$ \\
\hline Melting point & 2054 & 1870 \\
\hline
\end{tabular}

\section{Mould}

A metallic mould was made of cast iron with nine cylindrical shapes of diameter 20 $\mathrm{mm}$ and $13 \mathrm{~mm}$ height as shown in Fig. (2).

\section{Melting, Adding Powders and Pouring}

A charge of $3 \mathrm{Kg}$ of the base alloy was introduced to the crucible and heated up to the melting temperature (630 0C for A356 and 655 OC for A390). After reaching the liquid state the melt was degassed with either argon or hexacholorethane degasser Tablet before pouring, to get rid of gases. After degassing the melt was brought down to the semis-solid state $\left(590{ }^{\circ} \mathrm{C}-605^{\circ} \mathrm{C}\right.$ for A356 and 610 0C- $6150 \mathrm{C}$ for A390) and hence the nano- particles additions of $\mathrm{Al} 2 \mathrm{O} 3$ were prepared in packages of aluminum foil and preheated to $200 \mathrm{C}$ and then added to the melt simultaneously with mechanical stirring for $1 \mathrm{~min}$ at $1000 \mathrm{rpm}$. Table 3 summarizes the fabrication conditions of the composites prepared in this investigation. Cast samples were poured in the prepared mould without additions and with additions of the different investigated percentage additions. The prepared cast samples were hence used for further investigation.

\section{Material Characterization}

\section{Optical microscopy microstructure investigation}

Representative sections from the cast samples were cut into 3 pieces: the 1st from the top, the 2nd from the middle and the 3rd from the bottom. Samples were wet grounded on a rotating disc using silicon carbide abrasive discs of increasing finesse (120, 180, 220, 320, 400, 600, 800, 1000, and 1200 till 4000 grit). Then they were polished using 1 and $3 \mu \mathrm{m}$ diamond paste. This was followed by polishing and micropolishing using a vibrator polishing machine. The microstructure examination was carried out using optical metallurgical microscope equipped with a high resolution digital camera for investigating microstructure.

\section{Scanning Electron Microscope (SEM)}

The morphology of the primary phases and eutectic structure was further investigated using JSM-7000F SEM to detect the favorable sites for nano-particles incorporation and their influence on the microstructure features and formed precipitates by using back scattered electrons techniques. Samples of Back Scattered Electrons (BSE) were prepared and this process started by grinding them 
Table (3): List of produced alloys and fabrication conditions.

\begin{tabular}{|c|c|c|c|}
\hline $\begin{array}{l}\text { Base } \\
\text { Alloy }\end{array}$ & $\begin{array}{c}\text { Additions/ } \\
\text { designations }\end{array}$ & Melting conditions & $\begin{array}{l}\text { Pouring } \\
\text { conditions }\end{array}$ \\
\hline \multirow[b]{4}{*}{ A356 } & $0 \%$ & \multirow{4}{*}{$\begin{array}{l}\text { Degassing in liquid state, adding } \\
\text { nano-particles and mechanical } \\
\text { stirring for } 1 \mathrm{~min} \text { in semi-solid } \\
\text { state. }\end{array}$} & \multirow{4}{*}{$\begin{array}{l}\text { Pouring in semi- } \\
\text { solid state at } 605 \\
{ }^{\circ} \mathrm{C}\end{array}$} \\
\hline & $1 \% \mathrm{Al} 2 \mathrm{O} 3$ & & \\
\hline & $2 \% \mathrm{Al} 2 \mathrm{O} 3$ & & \\
\hline & $3 \% \mathrm{Al} 2 \mathrm{O} 3$ & & \\
\hline \multirow{5}{*}{ A390 } & $0 \% / A 390$ & \multirow{4}{*}{$\begin{array}{l}\text { Degassing in liquid state, adding } \\
\text { nano-particles and mechanical } \\
\text { stirring for } 1 \mathrm{~min} \text { in semi-solid } \\
\text { state. }\end{array}$} & \multirow{4}{*}{$\begin{array}{l}\text { Pouring in semi- } \\
\text { solid state at } \\
600^{\circ} \mathrm{C}\end{array}$} \\
\hline & $1 \% \mathrm{Al} 2 \mathrm{O} 3 / \mathrm{A} 1-600$ & & \\
\hline & $\begin{array}{l}0.5 \% \text { Al2O3 + 0.5\% } \\
\text { TiO2/ AT-600 }\end{array}$ & & \\
\hline & $\begin{array}{l}1 \% \text { Al2O3 + 0.5\% } \\
\text { TiO2/ AT1.5-600 }\end{array}$ & & \\
\hline & $\begin{array}{l}0.5 \% \text { Al2O3 + 0.5\% } \\
\text { TiO2/ AT-645 }\end{array}$ & $\begin{array}{l}\text { Degassing in liquid state, adding } \\
\text { nano-particles and mechanical } \\
\text { stirring for } 1 \text { min in liquid state }\end{array}$ & $\begin{array}{l}\text { Pouring in liquid } \\
\text { state at } 645^{\circ} \mathrm{C}\end{array}$ \\
\hline
\end{tabular}

followed by polishing and micro-polishing using a vibrator polishing machine. Some selected samples for SEM examination were prepared by cross section polishing with argon ions using Jeol SM09010-cross section polisher. Some selected samples for SEM examination were prepared by cross section polishing with argon ions using Jeol SM09010-cross section polisher

\section{Mechanical properties characterization}

Some mechanical properties of the investigated composites were determined in the as-cast treated and non-treated conditions; namely: tensile strength, ductility, and hardness.

\section{Tensile test}

Tensile test specimens were cut from the different aged bars and machined to the specified dimensions according to ASTM standard. Fig. 3 shows the standard specimen, and the main dimensions are listed in Table 4. Three test specimens were prepared for each condition only for A356.

\section{Hardness test}

The micro-hardness was measured for the A390 samples in order to further understand the relationship between the hardness of the micro-constituents and the overall hardness of the new material, as well as understanding the role of the nanoparticles on the hardness. The microhardness examination was carried out using Polyvar optical metallurgical microscope equipped with a high resolution digital camera for investigating microstructure, equipped also with Vickers micro-hardness tester. 
Table (4): The dimensions of the tensile specimens.

\begin{tabular}{|l|c|}
\hline \multicolumn{1}{|c|}{ Configuration } & Dimensions $(\mathbf{m m})$ \\
\hline G- Gage length & 45 \\
\hline D- Diameter & 9 \\
\hline R- Radius of fillet & 8 \\
\hline A- Length of reduced section & 54 \\
\hline C- Diameter of end section & 15 \\
\hline
\end{tabular}

The Overall hardness was also measured for the A356 alloys using Brinell hardness testing using $2.5 \mathrm{~mm}$ "diameter hardened steel ball and 31, and $62.5 \mathrm{~kg}$ applied load $(P / D 2=5,10)$. The reported results are the average of three reading.

\section{Corrosion Test}

\section{Potentio-dynamic corrosion test}

The corrosion test was conducted using Auto lab PGSTAT30 galvanostat/ potentiostat instrument, with $1 \mathrm{~cm}^{2}$ exposed area. The test solution used in these experiments was $3.5 \% \mathrm{NaCl}$ at the ambient temperature. The scan rate was 5 $\mathrm{mv} / \mathrm{sec}$.

\section{Immersion test}

The immersion corrosion test was conducted by suspending the disc shaped tested samples in $3.5 \% \mathrm{NaCl}$ aqueous solution. The specimens were ground, polished and cleaned by de-ionized water followed by rinsing with methanol and finally dried before the test. The specimens were exposed for 72 hours. After exposure the specimens were cleaned in $50 \%$ Vol. Nitric acid and dried. The results of the corrosion test were evaluated using weight loss measurements by using a digital balance. The corrosion rate in $\mathrm{mg} / \mathrm{cm} 2$ was transformed to $\mathrm{mm} / \mathrm{y}$ using the following relation: $\mathrm{mm} / \mathrm{y}=87.6 \times(\mathrm{W} / \mathrm{DAT})$ where $\mathrm{W}$ is weight loss in $\mathrm{mg}, \mathrm{D}$ is density in $\mathrm{gm} / \mathrm{cm} 3, A$ is area in $\mathrm{cm} 2$, and $T$ is the exposure time.

\section{Pin-on Disc Wear Test}

Wear test was conducted using a pin-on-disc technique at $265 \mathrm{rpm}$ and 0.4 bar applied load for 30 minutes long, running on a steel disk of 63 Rc hardness.

\section{RESULTS AND DISCUSSION}

\section{Hypoeutectic Alloy A356}

\section{Effect of nano additions on tensile strength of A356 alloy}

Figure (4) shows the average tensile strength for A356 base alloy without additions and with 1,2 , and $3 \%$ additions of Al2O3 nano-particles respectively. While Figure (5) shows the elongation \% averages for the same alloys respectively. Figure (4) indicates that the UTS changed from $117 \mathrm{MPa}$ for the base A356 alloy to $122 \mathrm{MPa}$ with $1 \%$ addition, to $157 \mathrm{MPa}$ with $2 \%$ addition to $150 \mathrm{MPa}$ with $3 \%$ addition. On the 
other hand the elongation \% changed from $2.1 \%$ for the base A356 alloy to $2.4 \%$ for $1 \%$ addition, $4 \%$ for the $2 \%$ addition, and $3.2 \%$ for the $3 \%$ addition, as can be seen from Fig. (5). From the two Fig. (4 and 5) it is evident that adding the nano-particles caused an increase in both tensile strength and elongation \% of the nanocomposites till $2 \%$ addition, afterwards a drop in both properties occurred.

Though it has been shown on many occasions including most recently [8] that the variability in tensile ductility in A356 cast alloys is usually attributed to the presence of large oxide films and residues of fluxes, grain refiners and modifiers; the statistical nature of improvement in ductility in alloys cast under the same conditions cannot be ignored.

\section{Effect of nano additions on hardness of A356 alloy}

Figure (6) shows the change in the hardness of the base alloy and the nanocomposite containing $1 \%, 2 \%$, and $3 \% \mathrm{Al}_{2} \mathrm{O}_{3}$ nano-particles respectively. The Figure reveals a continual increase in hardness with amount of nano-addition, though the drop in the hardness of the $1 \%$ nano-dispersed alloy is not understood at this stage.

\section{Effect of nano additions on microstructural features of A356 alloy}

The microstructural features of the prepared material obtained through this work are shown in figs. (7-8), where the influence of nano-particles addition is evident. The microstructure clearly indicates the presence of aluminum dendrites which tend to be spherodised in some areas after semi-solid casting and stirring. Table (5) and Fig. (9 and 10) show the influence of nanoparticles addition on some microstructure features namely; dendritic arm length, and inter-lamellar spacing in the eutectic silicon phase. It is seen from this Table that the addition of $1 \mathrm{wt} \%$ has caused a decrease in the dendrite arm length average value from $24.91 \pm 11.3$ to $20.4 \pm 6.5$, and the inter-lamellar spacing in the eutectic silicon phase from $3.795 \pm 1.61$ to $2.475 \pm 1.05$. The decrease in these measurements is an indication of a probable refining effect induced by the addition of the nano particles. The decrease in the difference between minimum and maximum length of dendrite spacing represented by the decrease in the standard deviation indicates the tendency of the $\alpha-\mathrm{Al}$ dendrites to change to more rounded or spheroid shape to be more globular or rounded. Similar behavior has been reported [3], though the alloys were manufactured in a different manner the researchers [3] have found that the addition of $\mathrm{Al}_{2} \mathrm{O}_{3}$ particles to $\mathrm{A} 356$ alloy has reduced the grain size of the aluminum matrix, it has been also shown that there is variation in the porosity with the particles content. Yet great enhancement in the tensile properties was reported for the nano-reinforced alloy both in this work and in other literature [3].

\section{Hypereutectic Alloy A390}

\section{Microstructure and microhardness}

The microstructure of the investigated hypereutectic Al-Si alloys consists of three different phases; namely: primary silicon particles, eutectic structure, and $\alpha-A l$. The hardness values of those phases contribute somehow to the overall hardness of the alloys, Fig. (11).

Table (6) presents the micro-hardness values for the identified phases in the new developed alloys with different nano-additions, each value represents an average of 
Table (5): Influence of nanoparticles addition on some microstructure features.

\begin{tabular}{|l|c|c|c|c|}
\hline \multirow{2}{*}{ Alloy 3*} & \multicolumn{2}{|c|}{$\begin{array}{c}\text { Interlaminar } \\
\text { Spacing }(\boldsymbol{\mu m})\end{array}$} & \multicolumn{2}{c|}{$\begin{array}{c}\text { Dendrite arm length } \\
(\boldsymbol{\mu m})\end{array}$} \\
\cline { 2 - 5 } & Average & $\begin{array}{c}\text { Standard } \\
\text { d7eviation }\end{array}$ & Average & $\begin{array}{c}\text { Standard } \\
\text { deviation }\end{array}$ \\
\hline $\mathbf{A 3 5 6}$ & 5.02 & \pm 1.61 & 24.91 & \pm 11.3 \\
\hline $\begin{array}{l}\mathbf{A 3 5 6}^{3} \mathbf{1} \% \\
\mathbf{A l}_{\mathbf{2}} \mathbf{O}_{\mathbf{3}}\end{array}$ & 3.42 & \pm 1.05 & 20.40 & \pm 6.5 \\
\hline
\end{tabular}

Table (6): Micro-hardness values.

\begin{tabular}{|l|c|c|c|c|c|}
\hline & Monolithic & A1-600 & AT-600 & AT-645 & AT1.5-600 \\
\hline $\begin{array}{l}\text { Primary Si } \\
(\mathrm{HV})\end{array}$ & 1821 & 1405 & 2149 & 2165 & 2033 \\
\hline $\begin{array}{l}\text { Eutectic } \\
\text { structure } \\
(\mathrm{HV})\end{array}$ & 169 & 185 & 184 & 173 & 170 \\
\hline$\alpha-\mathrm{Al}(\mathrm{HV})$ & 159 & 169 & 176 & 165 & 139 \\
\hline
\end{tabular}

of about 5 readings. A significant variance is evident between the hardness values of the primary silicon particles and the other phases, i.e. eutectic structure, and $\alpha-\mathrm{Al}$.

The primary silicon phase, which the overall hardness of the alloy is highly affected by its presence, shows very high values of hardness in all samples; yet, the highest values is associated with the presence of $0.5 \% \mathrm{TiO}_{2}$, also analysis shows that, silicon particle size plays a role in its hardness value; as the silicon particles size increase the hardness value increases. An overall improvement in micro-hardness values was reported for all phases upon the addition of the nano-particles, as can be seen in Table (6). As shown from Table (5) an improvement in the hardness values occurs with nano-particles addition. The enhancement in hardness for the nanodispersed materials is highly believed (as will be shown later) to be related to the refining effect of the nano-particles on the primary silicon particles as well as on the other microstructure features.

\section{Microstructure and hardness of A390 alloy}

Figure (12) shows a presentation of variation in hardness of investigated material with different additions. The Fig. indicates that the highest overall hardness is observed for the alloy AT-600. The results agree with the results obtained from the 
microhardness test where the hardness of the is particles seem to be of dominance in controlling the overall hardness.

\section{Effect of nano additions on microstructural features of A390 alloy}

The microstructure of the developed alloys was investigated for many selected samples. As shown before the microstructure of the investigated A390 alloy consists of primary Si particles in addition to aluminium phase in dendritic or equi-axed form as well as binary Al-Si structure as shown in Fig. (13). The morphology of the primary silicon in all the studied samples remains as polygonal except in the sample containing $1 \% \mathrm{Al}_{2} \mathrm{O}_{3}$ where little primary silicon particles in needle like shape were spotted (13 a). Moreover, it is shown from the micrograph (13 a) that the eutectic silicon has two morphologies, one is present in spaces between $\alpha$-Al dendrite arms and it can be found to be fine, skeleton network with Chinese script morphology [9]; the second one can be found around the primary silicon particles and it is in the shape of flakes $13 \mathrm{~b}$ ).

Table (7) and Figure (14) show the influence of nanoparticles addition on some microstructure features namely; dendritic arm length, interdendritic arm spacing and interlamellar spacing in the eutectic silicon phase.

The narrowing of the range of scatter in the size of micro constituents (Fig. 15) with the processing method developed in this work is obvious. Previous findings have found increased Si particles segregation due to rheo-casting [9] and were explained to be resulting from the shear forces during stirring while solidification occurs. Also an overall trend for size decrease was apparent in the studied samples except for the material containing $0.5 \% \quad \mathrm{Al}_{2} \mathrm{O}_{3} \& 0.5 \% \quad \mathrm{TiO}_{2}$ cast in semi-solid state which revealed a wide scatter in the silicon particles size, whilst the sample material $0.5 \%$ $\mathrm{Al}_{2} \mathrm{O}_{3} \& 0.5 \% \mathrm{TiO}_{2}$ cast in liquid state has shown relatively higher content of refined primary silicon particles, though these results maybe an effect of non-homogeneous processing conditions, further study of the role of adding $\mathrm{TiO}_{2}$ in liquid state should be investigated..

\section{Effect of nano additions on results of pin-on-disc wear test}

The wear test was conducted in two different conditions as follows:

1) Rotational speed of $265 \mathrm{rpm}$, load 0.4 bar, and for 30 minutes long.

2) Rotational speed of $265 \mathrm{rpm}$, load 0.5 bar, and for 15 minutes long.

Figure 16 illustrates the wear test results to the hardness values of the developed material, and shows that the sample which has the highest wear resistance was the sample containing $0.5 \% \mathrm{Al}_{2} \mathrm{O}_{3} \& 0.5 \% \mathrm{TiO}_{2}$ and cast in semi-solid state, agreeing with hardness results.

\section{Results of Corrosion Tests}

\section{Potentiodynamic corrosion test}

Figure (17) shows a graphical presentation of the potentio-dynamic corrosion test results, the Fig. shows that the semi- solid cast A390 alloys containing nano-sized dispersions show a general enhancement in the corrosion resistance (by the potentio-dynamic test) compared to both the monolithic and the nano-dispersed alloy cast from the liquid state. The $\mathrm{A} 390$ alloys containing $1 \% \mathrm{Al}_{2} \mathrm{O}_{3}, 0.5 \% \mathrm{Al}_{2} \mathrm{O}_{3} \& 0.5 \%$ $\mathrm{TiO}_{2}$, and $1.0 \% \mathrm{Al}_{2} \mathrm{O}_{3} \& 0.5 \% \mathrm{TiO}_{2}$ cast in semi-solid condition showed significant 
Table (7). Influence of nanoparticles additions on the dendritic arm length, interdendritic arm spacing and interlamllar spacing for the studied samples.

\begin{tabular}{|l|c|c|c|c|c|c|}
\hline & \multicolumn{2}{|c|}{$\begin{array}{c}\text { Interdendritic arm } \\
\text { spacing }(\mu \mathrm{m})\end{array}$} & \multicolumn{2}{|c|}{$\begin{array}{c}\text { Dendrite arm length } \\
(\mu \mathrm{m})\end{array}$} & \multicolumn{2}{|c|}{$\begin{array}{c}\text { Interlamellar spacing } \\
(\mu \mathrm{m})\end{array}$} \\
\hline Alloy A390 & $\begin{array}{c}\text { Average } \\
(\mu \mathrm{m})\end{array}$ & $\begin{array}{c}\text { Data range } \\
(\mu \mathrm{m})\end{array}$ & $\begin{array}{c}\text { Average } \\
(\mu \mathrm{m})\end{array}$ & $\begin{array}{c}\text { Data range } \\
(\mu \mathrm{m})\end{array}$ & $\begin{array}{c}\text { Average } \\
(\mu \mathrm{m})\end{array}$ & $\begin{array}{c}\text { Data range } \\
(\mu \mathrm{m})\end{array}$ \\
\hline Monolithic & 58.83 & 41.6 to 80 & 200.72 & 173.6 to 232 & 10.64 & 6.8 to 13.8 \\
\hline A1-600 & 44.50 & 31.5 to 53 & 119.94 & 106.7 to 138 & 4.74 & 3.2 to 7.36 \\
\hline AT-600 & 35.60 & 28 to 40 & 114.94 & 91.7 to 143 & 5.78 & 4.3 to 7.3 \\
\hline AT-645 & 43.82 & 40.22 to 52 & 151.38 & 128.9 to 175 & 7.42 & $\begin{array}{c}5.025 \text { to } \\
10.62\end{array}$ \\
\hline AT1.5-600 & 36.00 & 32 to 40 & 60.00 & 56 to 64 & 7.54 & 4.22 to 10.8 \\
\hline
\end{tabular}

improvement in the corrosion resistance compared to both the monolithic alloy A390 and the alloy with $1 \% \mathrm{TiO}_{2}$ addition cast from the liquid state. The results also show that the polarization resistance increased with the addition of $1 \% \mathrm{Al}_{2} \mathrm{O}_{3}$, and $0.5 \%$ $\mathrm{Al}_{2} \mathrm{O}_{3}$ with $0.5 \% \mathrm{TiO}_{2}$, perhaps indicating the formation of a protective layer.

\section{Static immersion test}

Similarly, Figure (18) shows the results obtained by the static immersion test. The results show different results than that obtained by potentiodynamic test. The least corrosion loss in $\mathrm{mg} / \mathrm{cm}^{2}$ was obtained for the alloy containing a higher $\mathrm{Al}_{2} \mathrm{O}_{3} \%(1 \%)$ associated with $0.5 \% \mathrm{TiO}_{2}$.

\section{CONCLUSIONS}

At this stage of findings for the ongoing research it was found that:

1. Nano-particles could be successfully incorporated into semi-solid slurries of AISi hypoeutectic alloys by inducing mechanical stirring, though more work need to be done to achieve conditions for homogeneous dispersion.

2. The addition of the preheated reinforced particles in the semi-solid state enhances the wettability of the reinforcement with the matrix compared to the wettability when reinforcement is made in the liquid state and this was reflected by the poor properties of the material prepared in liquid state in this work.

3. The introduced nano-sized particles at different ratios produce a significant refining effect on the microstructure features of both the A390 hypereutectic aluminum-silicon alloys where an obvious refining in the primary silicon particles average size from 30-40 $\mu \mathrm{m}$ to $10-20 \mu \mathrm{m}$ occurred in the A390 alloy after adding $1 \% \mathrm{Al}_{2} \mathrm{O}_{3}$ combined with $0.5 \% \mathrm{TiO}_{2}$.

4. Introducing $1 \% \mathrm{Al}_{2} \mathrm{O}_{3}$ combined with $0.5 \% \quad \mathrm{TiO}_{2}$ nano-particles to the $\mathrm{AISi}$ hypoeutectic semi-solid cast alloys produces a decrease in the dendrite arm length average value from $24.91 \pm 11.3 \mu \mathrm{m}$ to $20.4 \pm 6.5 \mu \mathrm{m}$, and the interlamellar spacing in the eutectic silicon phase from $3.795 \pm 1.61 \mu \mathrm{m}$ to $2.475 \pm$ $1.05 \mu \mathrm{m}$. 
5. The introduction of the nano-sized particles led to an increase in the hardness of both alloys in the as-cast state: reaching the maximum of $40 \%$ to the hypereutectic alloy, and $31 \%$ to the hypoeutectic alloy.

6. Introducing $2 \% \mathrm{Al}_{2} \mathrm{O}_{3}$ nano-particles to the AISi hypoeutectic semi-solid cast alloys produces $34 \%$ increase in strength, and $90 \%$ ductility of the alloys, and produces a $39.5 \%$ increase in strength and $26.4 \&$ ductility of the alloys in the T6 condition.

7. Significant changes have been found in the wear resistance of the tested material after adding nano-sized particles.

8. Significant changes have been found in the corrosion performance of the tested material after adding nano-sized particles. Further investigation is requested.

\section{ACKNOWLEDGEMENT}

The present study was part of a big research project on developing nanodispersed cast light aluminum and magnesium alloys, for investigating options for enhancing their properties and performance in automotive applications. The project was supported by the facilities of: British University in Egypt BUE; Scientific \& Technology Centre of Excellence Salam City; Department of Mechanical engineering Cairo University; Department of Mechanical Engineering Helwan University; and the Gemeinshaftslabor fuer Elektronmikroskopie Aachen, Germany. The exchange of visits between Egypt and Germany was funded by both Science and Technology Development Funding Office STDF and Deutsche Akademishe Austaush Dienst DAAD. For the sake of this conference focus will be made on the results of Al-Si hypo and hyper eutectic alloys.

\section{REFERENCES}

[1] El-Mahallawi I. S., Eigenfeld K., Kouta F. H., Hussein A., Mahmoud T. S., Ragaie R. M., Shash A. Y., Abou-Al-Hassan W.," Synthesis and characterization of new cast $\mathrm{A} 356 /\left(\mathrm{Al}_{2} \mathrm{O}_{3}\right)_{\mathrm{p}}$ metal matrix nano-composites" Proceedings of the $2^{\text {nd }}$ Multifunctional Nanocomposites \& Nanomaterials: International Conference and Exhibition, Sharm El-Sheikh, Egypt Jan. 11-13, (2008).

[2] El- Mahallawi I.S., Shash Y., Eigenfeld K., Mahmoud T.S., Ragaie R.M., Shash A.Y. and El Saeed M.A..:"Influence of Nanodespersions on Strength ductility properties of semisolid cast Al Alloy", Material Science and Technology, Vol 26 (10), (2010).

[3] Yong Yang, Jie Lan, Xiaochum Li. Material Science Engineering.:"Study on bulk aluminum matrix nano-composite fabricated by ultrasonic dispersion of nano-sized Sic particles in molten aluminum alloy" , A380, PP 378-383, (2004).

[4] Mazahery A., Baharvandi H.R., and Abdizadeh H.:"Development of high performance A356-nano Al2O3 composites", Material Science Engineering, A518, PP 23-27, (2009).

[5] Suel-Ki Park, Jin-Myung Choi, Yong-Jin Kim, Ik-Min Park, and Yong-Ho Park, "Effect of Reinforcement On Sliding Wear Behaviors of Hypereutectic Al-Si Composites Prepared By Powder Metallurgy", Surface Review and Letters, Vol.17, No.2, PP 257-260, (2010). 
[6] Jinmyung Choi, Suelki Park, Bonggyu Park, Ikmin Park, and Yongho Park, "Characterization of Hypereutectic Al-20wt\% Si/ TiCp Metal Matrix Composite", International Journal of Modern Physics B, Vol.23, Nos. 6\& 7, PP 1491-1496, (2009).

[7] Suelki Park, Jinmyung Choi, Bonggyu Park, Ikmin Park, and Yongho Park, "Microstructure And Mechanical Properties Of Hypereutectic Al-Si/AINp Composite", International Journal of Modern Physics B, Vol.23, Nos. 6\& 7, PP 1377-1382, (2009).

[8] Gokhale A. M., Patel G. R.; Analysis of variability in tensile ductility of a semisolid metal cast A356 Al-alloy; Materials Science and Engineering A 392, PP 184-190, (2005).

[9] Alireza Hekmat-Ardakan, Frank Ajersch, Journal of Materials processing Technology, Vol 210, PP. 767-775, (2010).

\section{Figures:}

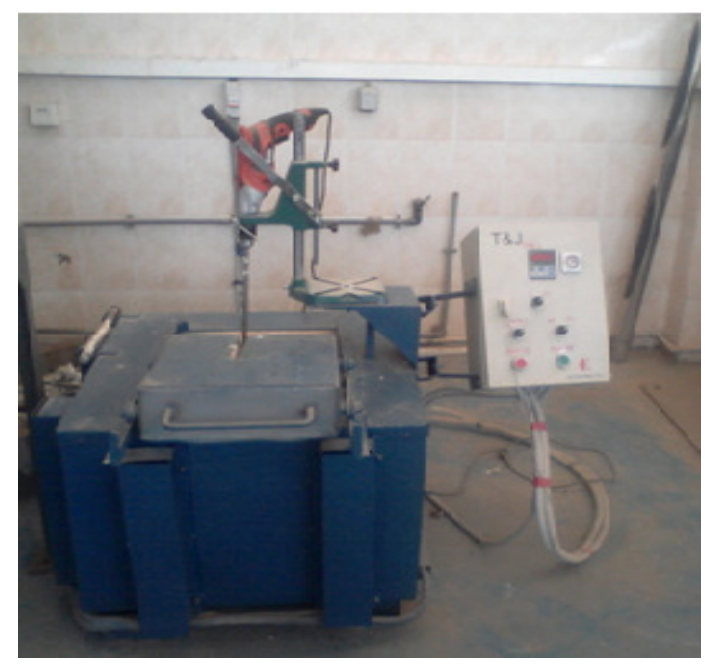

Fig. (1). Electrical Furnace.

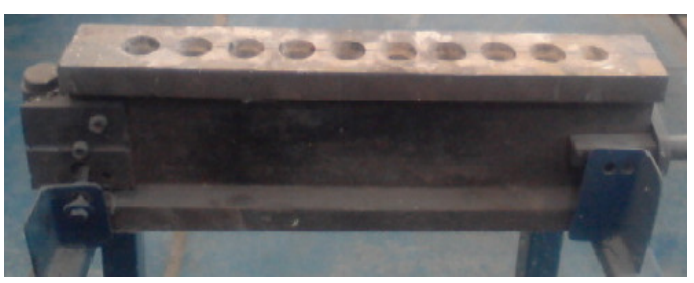

Fig. (2). Cylindrical Metallic Mould. 


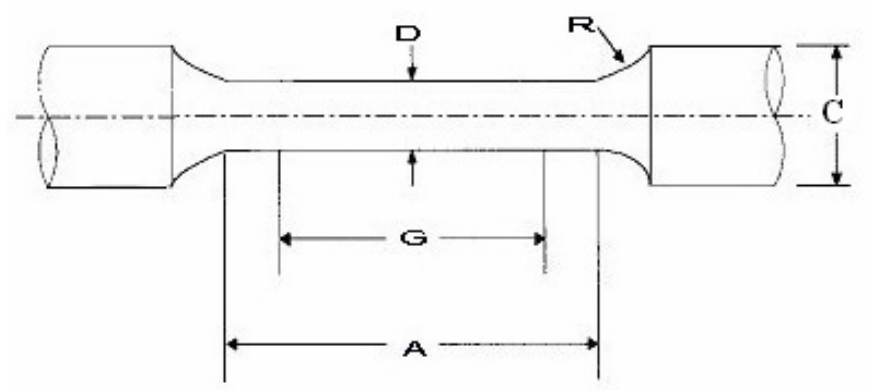

Fig. (3) Standard tensile specimen according to ASTM.

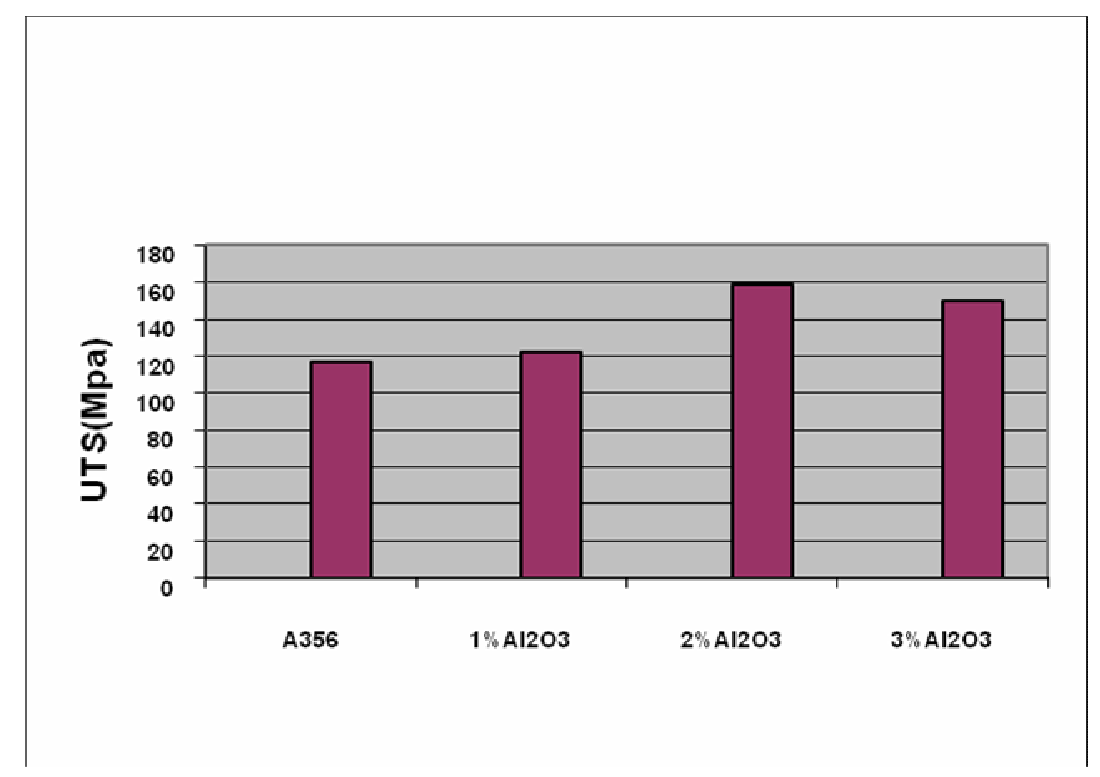

Fig. (4) Change in UTS with nano-particles additions.

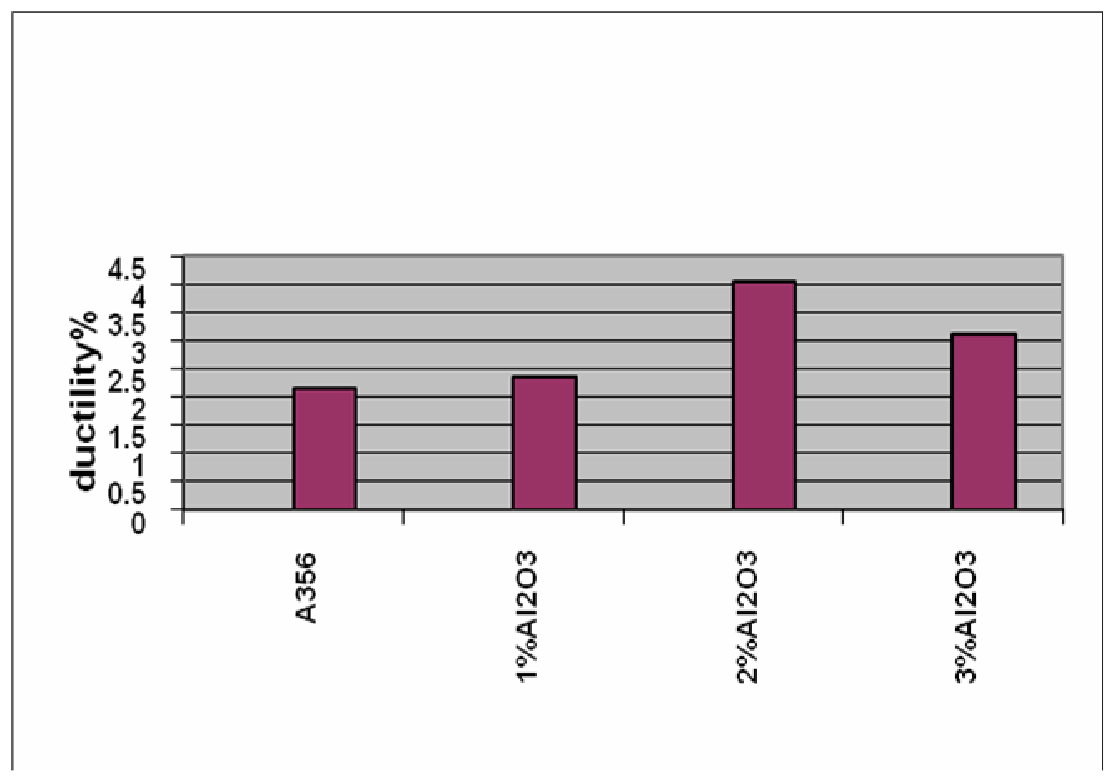

Fig. (5) Change in elongation \% with nano-additions. 


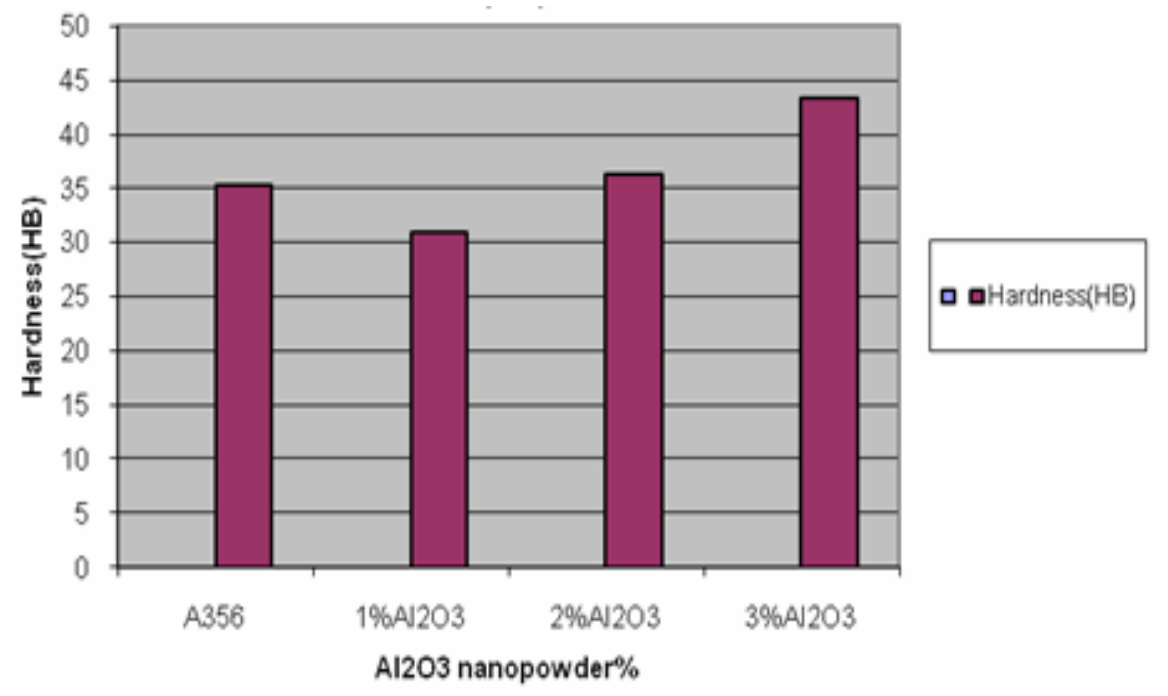

Fig. (6) Effect of nano additions on hardness of A356 alloy.
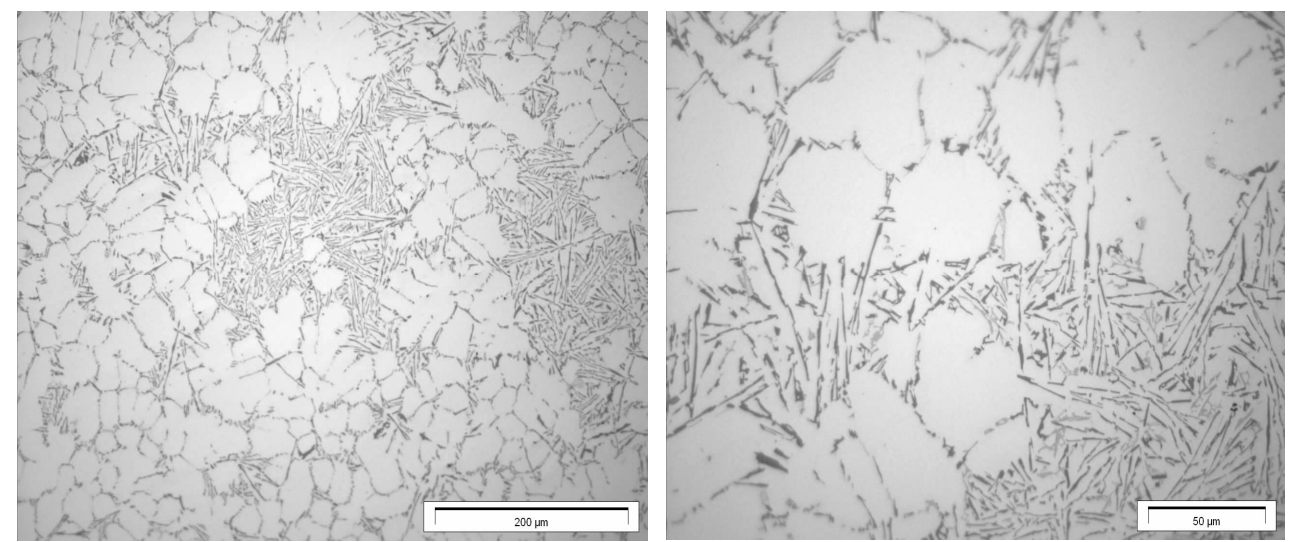

Fig. (7) Micrographs show the microstructure of as cast A356 without particles addition and with stirring time $1 \mathrm{~min}$ ) that cast in semi solid state at $600 \cdot \mathrm{C}$ and poured in cylindrical cast iron mould heated to $400 \circ \mathrm{C}$ a) at $\times 200$ magnification, b) at $\times 500$ magnification.
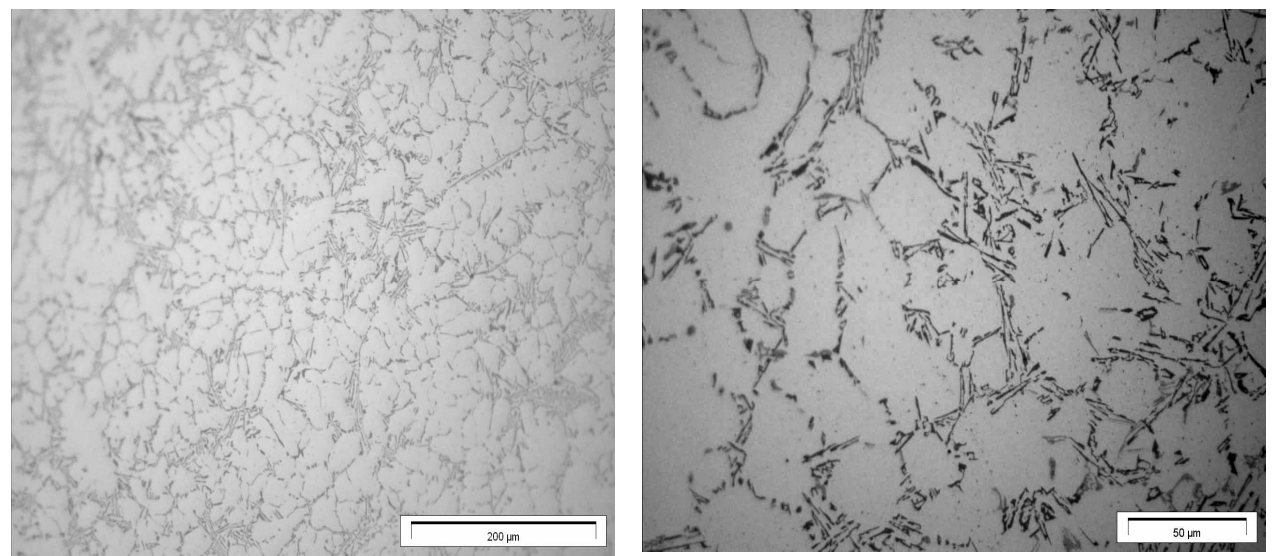

Fig. (8) Micrographs show the microstructure of cast No. 6 . (i.e. A356 $+1 \% \mathrm{Al} 2 \mathrm{O} 3$ nanoparticles with stirring time $1 \mathrm{~min}$ ) that cast in semi solid state at 620 . ${ }^{\circ} \mathrm{C}$ and poured in rectangular cast iron mould heated to $400 \circ \mathrm{C}$ a) at $\times 100$ magnification, b) at $\times 500$ magnification 
A356 without additions

A356 with additions
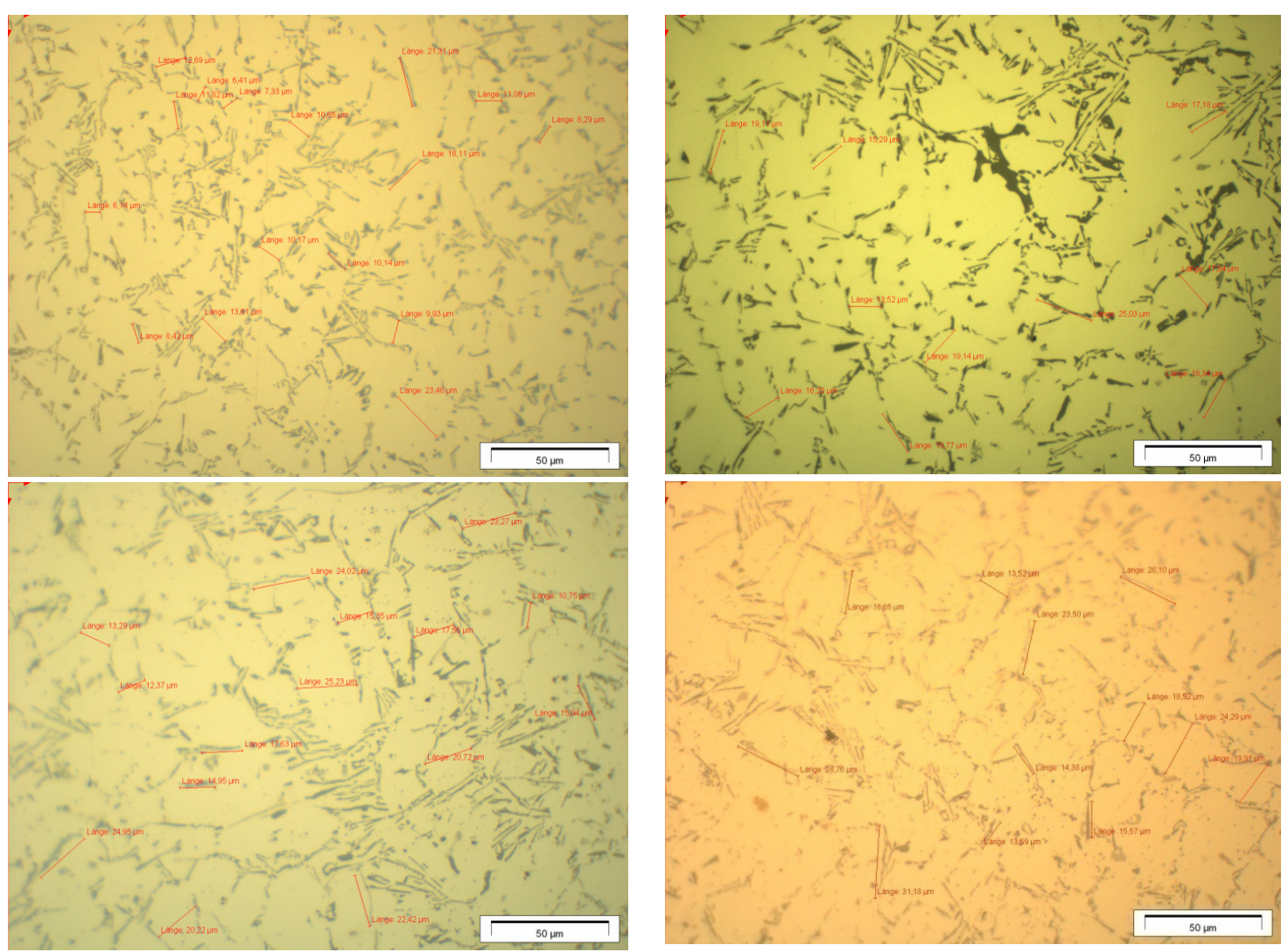

Fig. (9) Microstructural features of hypoeutectic A356 alloy before and after nanoparticles additions.

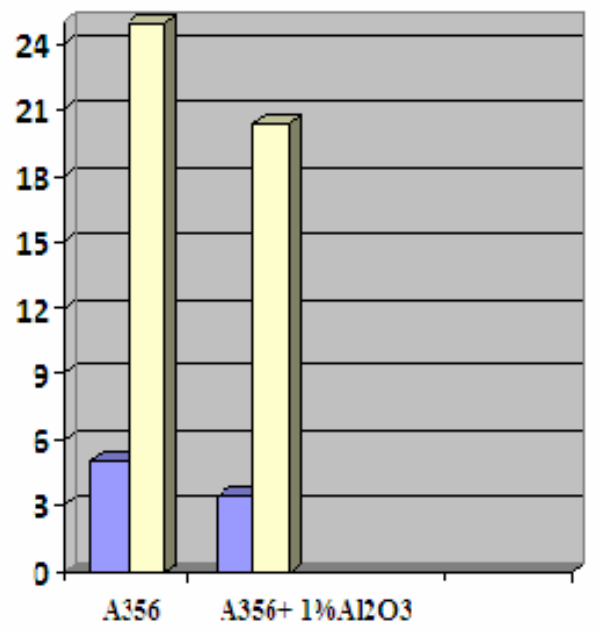

Fig. (10) Influence of nanoparticles addition on some microstructure features. 


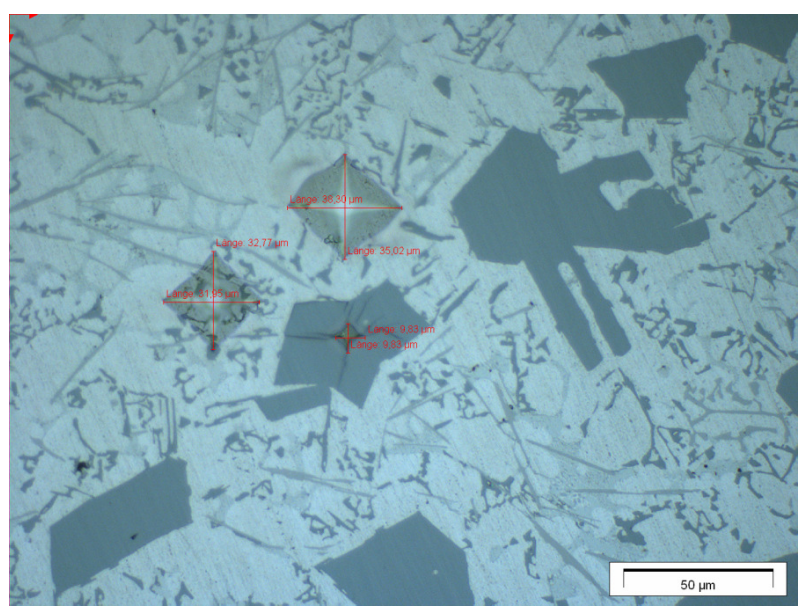

Fig. (11): Micrograph of the monolithic alloy used for microhardness.

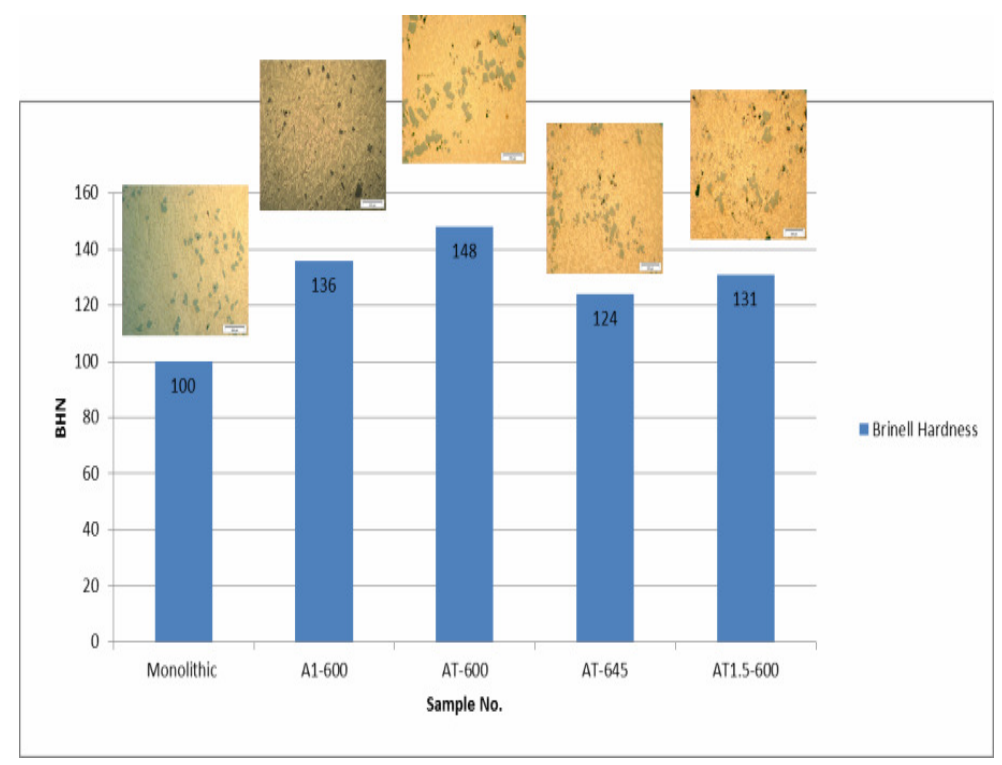

Fig.(12) change in hardness with Nano-particles additions.
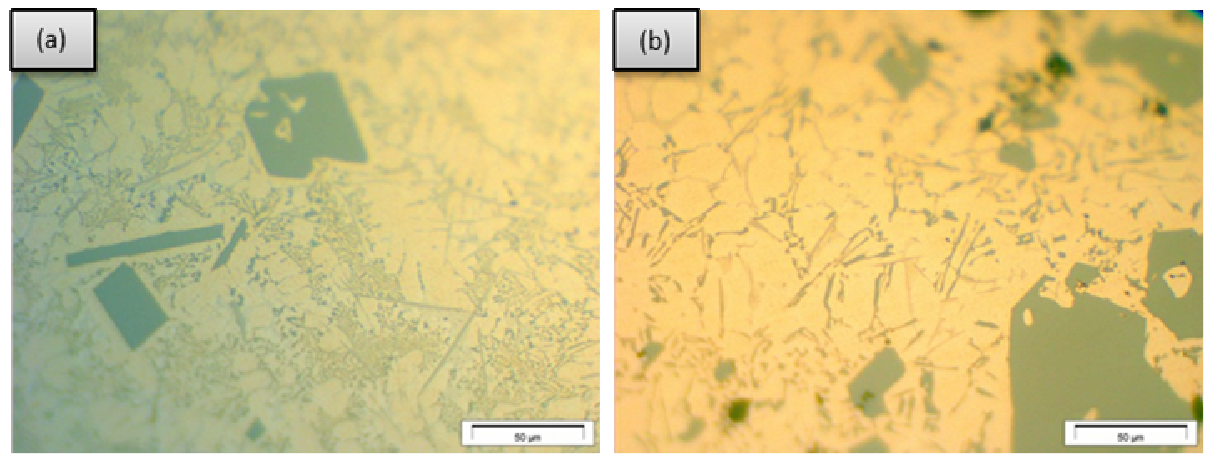

Fig.(13) Eutectic Silicon morphologies in (a) fine, skeleton network with Chinese script morphology in sample containing $1 \% \mathrm{Al} 2 \mathrm{O} 3$ cast in semi-solid state, (b) flakes surrounding primary silicon particles in sample containing $1 \% \mathrm{Al} 2 \mathrm{O} 3 \& 0.5 \% \mathrm{TiO} 2$ cast in semi-solid state. 


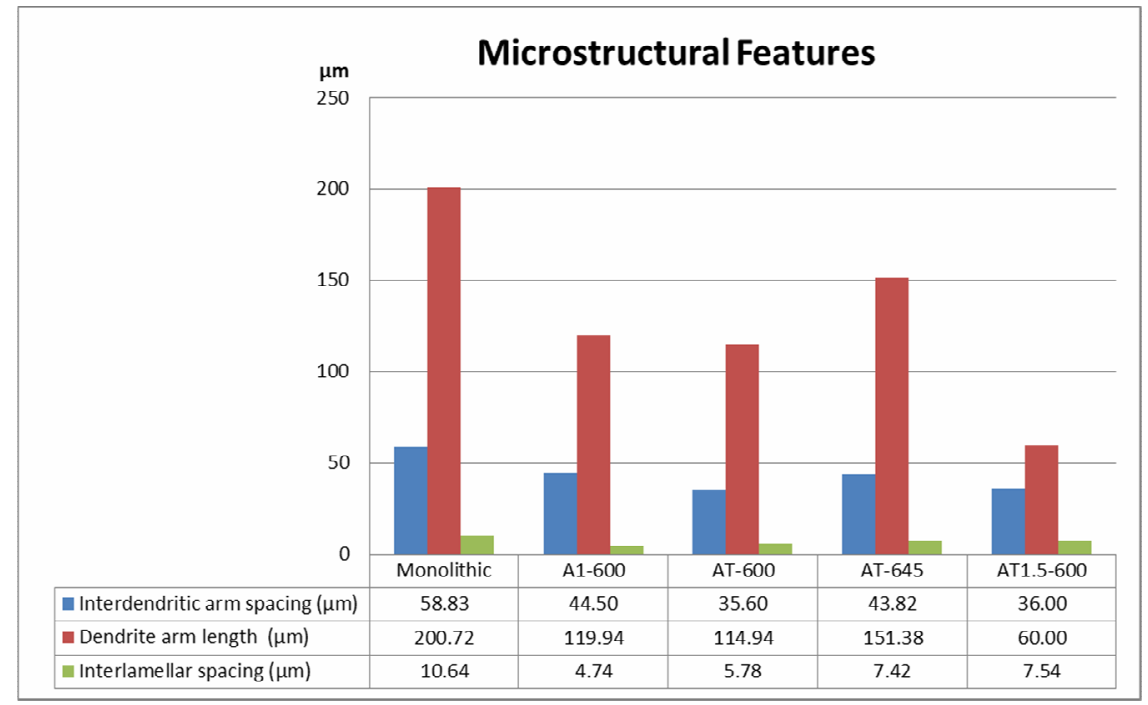

Fig. (14) Values of interdendritic arm spacing, dendrite arm length, and interlamellar spacing for the investigated samples.
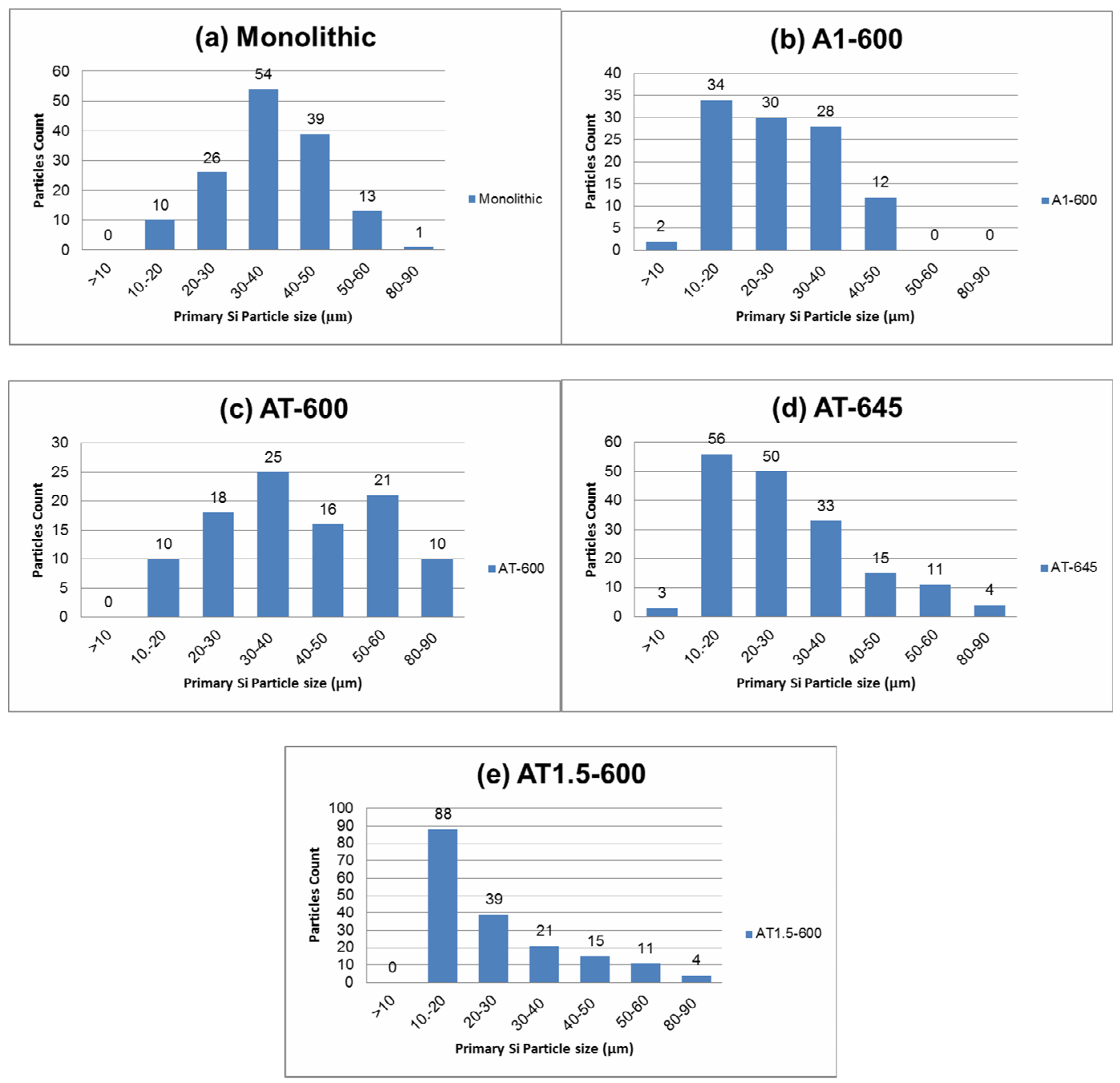

Fig.(15) primary silicon size analysis for: (a) monolithic cast A390 alloy, (b) A390 containing $1 \% \mathrm{Al}_{2} \mathrm{O}_{3}$ cast in semi-solid , (c) $0.5 \% \mathrm{Al}_{2} \mathrm{O}_{3}+0.5 \%$ TiO2 cast in semi-solid , (d) $0.5 \% \mathrm{Al}_{2} \mathrm{O}_{3}$ $+0.5 \mathrm{TiO}_{2}$ cast in liquid, (e) $1 \% \mathrm{Al}_{2} \mathrm{O}_{3}+0.5 \mathrm{TiO}_{2}$ cast in semi-solid. 


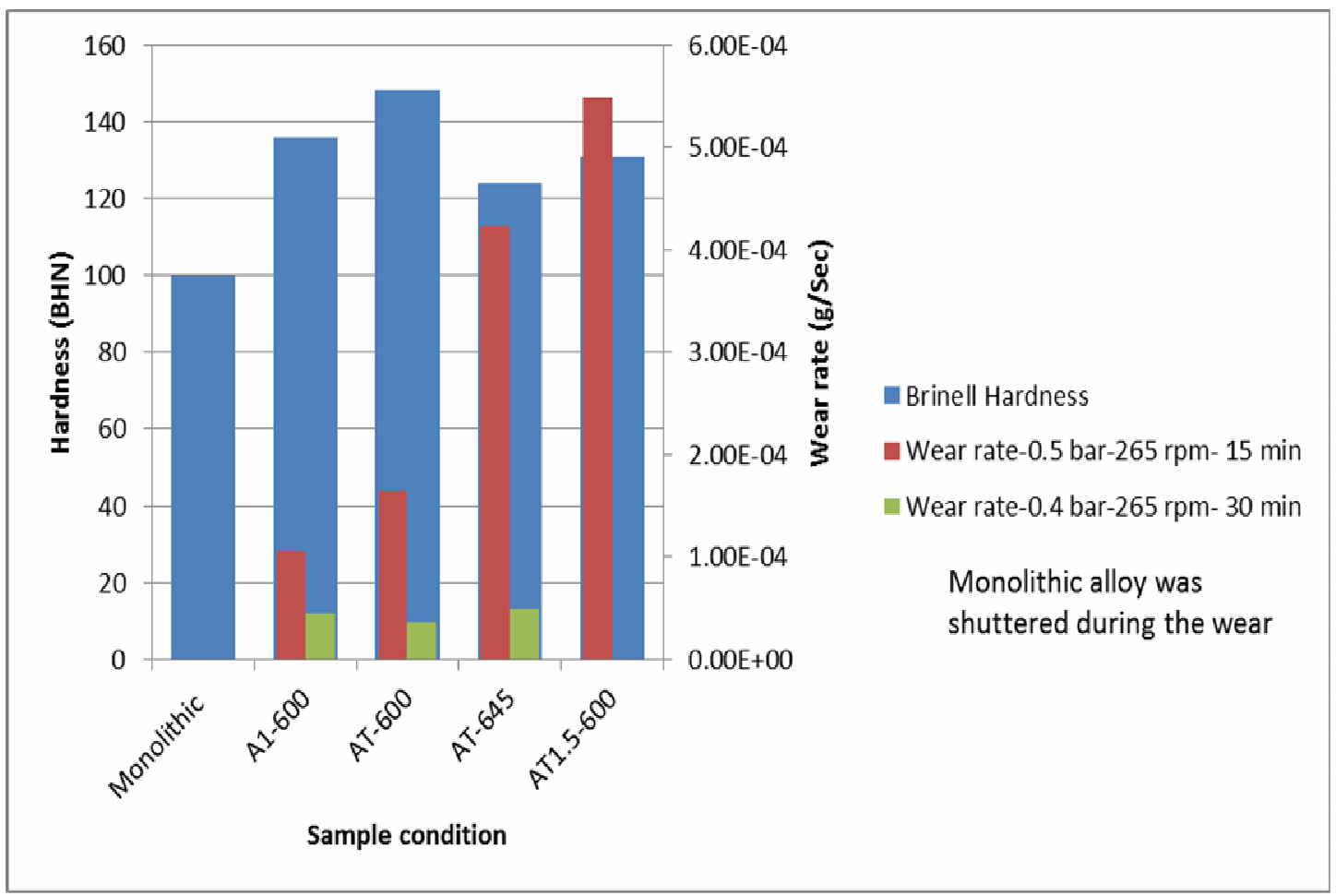

Fig. (16) Wear rate against Brinell hardness and sample manufacturing condition.

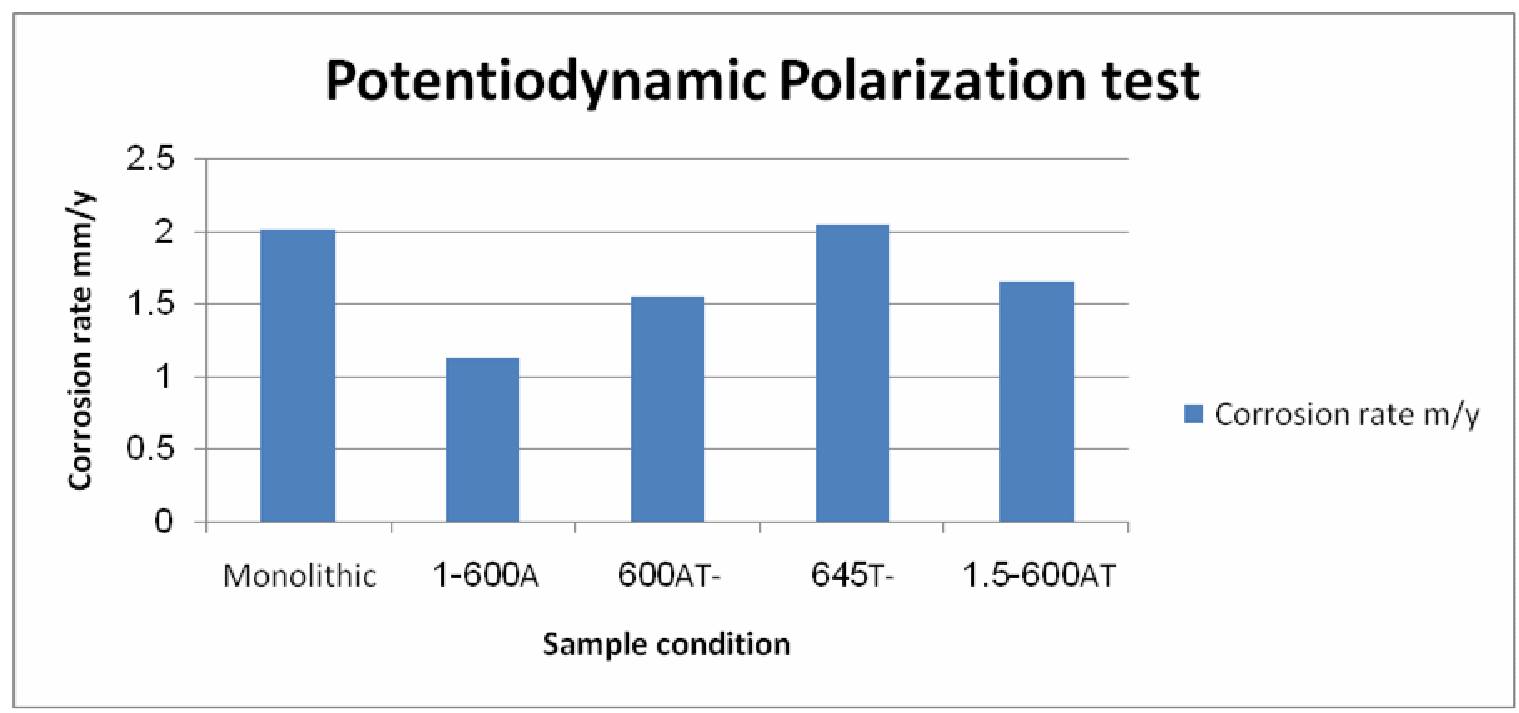

Fig (17) Results of the potentio-dynamic corrosion test. 


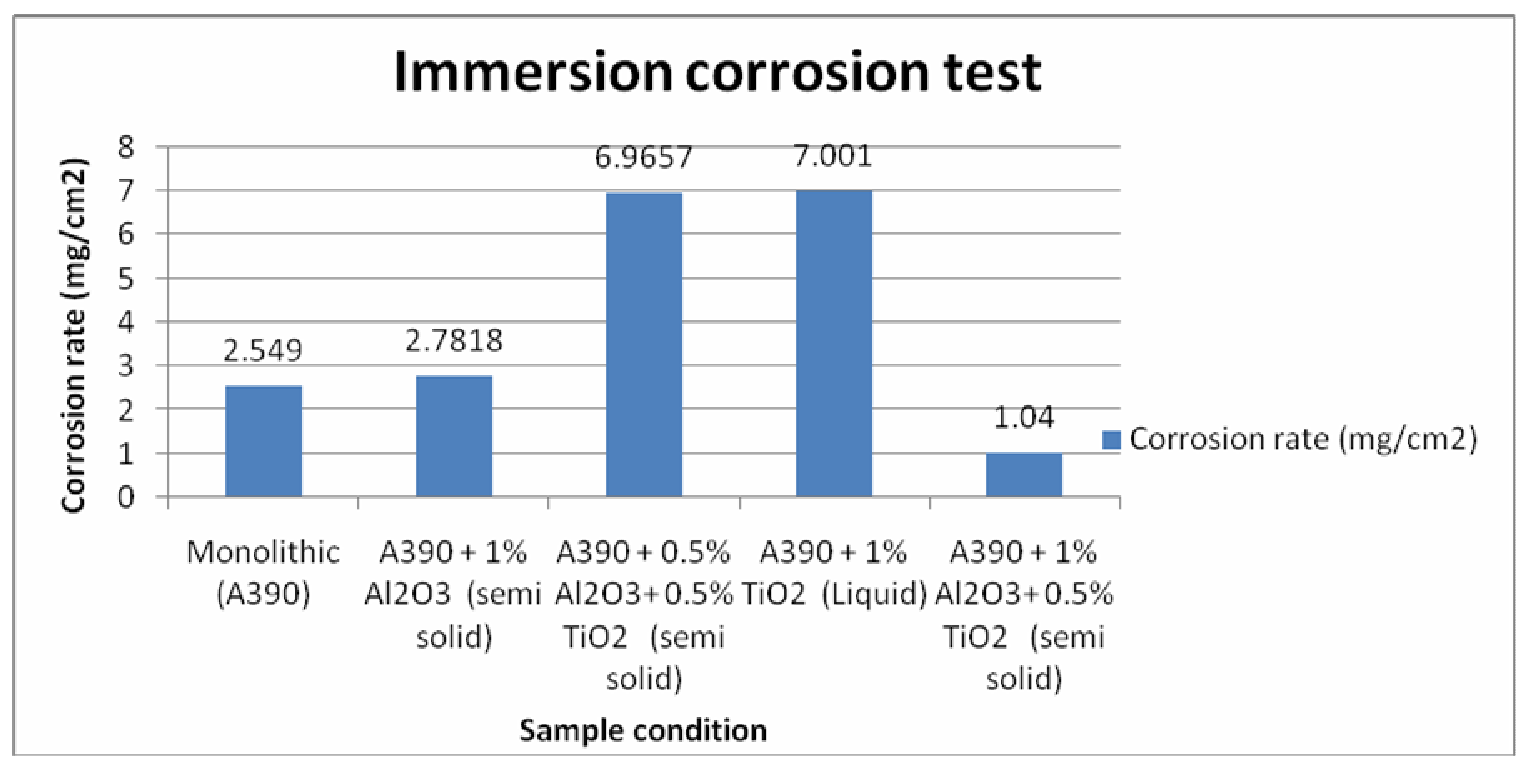

Fig (18) Results of the immersion corrosion test. 